\title{
EFFECTS OF SALINITY ON THE GROWTH, SURVIVAL AND PROXIMATE COMPOSITION OF PANGAS, PANGASIUS HYPOPHTHALMUS
}

\author{
Shankar Chandra Mandal, Shahin Kadir and Anwar Hossain*
}

Department of Fisheries, University of Dhaka, Dhaka-1000, Bangladesh

\begin{abstract}
Climate change induced salinity intrusion has a global and local effect on the aquaculture production. Thai-Pangas (Pangasius hypophthalmus) has become one of the cheapest protein sources in Bangladesh because of its wide range of environment tolerance, excellent growth and survival rate. Present study was thus conducted to measure the effects of salinity on the growth performance and survival of pangas. For the determination of the effect of salinity on growth and survival, 15-day old fingerlings were reared in $0,2,4,6,8,10,12,14$ and $20 \%$ o for 60 day at laboratory condition. All fish fingerlings in treatment with $20 \%$ o salinity died within 6 hours of stocking while $62.5 \%$ mortality was found within 6 hours at $14 \%$ o salinity. No mortality was detected in other treatment groups. Significantly higher specific growth rate was detected at 0,2 and 4\%o salinity than that of 12 and $14 \%$ o salinity. No significant change in food conversation ratio was found among treatments. No significant difference was observed on proximate composition between and within treatments. Water quality parameters include temperature, dissolved oxygen and $\mathrm{pH}$ were $27.23 \pm 0.02{ }^{\circ} \mathrm{C}, 8.33 \pm 0.05 \mathrm{mg} / \mathrm{L}$ and $8.05 \pm 0.03$, respectively throughout the experimental period. Thus, the present study suggests the suitability of pangas fingerlings at up to $4 \%$ o saline water with desirable growth rate.
\end{abstract}

Key Words: Salinity intrusion, Thai Pangas fingerings, Feed conversion ratio, Water quality.

\section{INTRODUCTION}

Being anagro-based riverine country, Bangladesh is enriched with vast fisheries resources which contribute $3.5 \%$ to the GDP, $25.71 \%$ to the agricultural products and $1.5 \%$ to the export earnings (DoF 2018). A major portion of the protein demand comes from fish contributing about $60 \%$ in the diet of the Bengali people (DoF 2019). However, people of the lower income level cannot fulfill the demand of protein.

Bangladesh is going to be affected by global climate change and sea level rise. Millions of coastal inhabitants of Bangladesh will lose their livelihoods and heritage. Particularly, agricultural and aquaculture activities will be severely affected by several physico-chemical factors especially by saline water intrusion. Under this circumstances, it is better to find the ways how to adjust with the adverse climatic conditions. So, for the enhanced economic growth, researches in several agricultural sectors like aquaculture, horticulture, paddy culture are important to develop new and sustainable technologies to adjust with the saline challenged situation. Certain level of salinity has been shown to be positively correlated with growth of fish (Lemarie et al. 2004) where metabolism influences

Author for correspondence: <ahossain@du.ac.bd>

(C2020 Zoological Society of Bangladesh DOI: https://doi.org/10.3329/bjz.v48i1.47883 
the proportion of energy intake allocated to growth (Sun et al. 2006), determination of optimum salinity might be useful in increasing pangas production.

Growth performance of fish largely depends on feed consumption and its assimilation and conversion into body tissues (Burel et al. 1996). However, several internal factors including endocrine system and environmental factors including salinity control the growth and food intake of fish. Salinity has been shown as one of the most significant environmental parameters influencing survival, growth and distribution of fish both in freshwater and marine habitat (Imsland et al. 2001). Salinity can directly impact on the survival of fish by decreasing feeding rate and by altering the energy cost for osmotic and ionic regulation (Boeuf and Payan 2001). Salinity, like other environmental factors specific to aquatic habitats, has provoked many studies on its influence on the growth of fish (Rubia et al. 2005). Salinity can potentially act as a stressor in aquaculture condition (Varsamos et al. 2004). Very few studies have been conducted on the effects of salinity on fish survival and nutritional quality. Understanding the effects of salinity on the growth and survival of pangas fingerlings can help to evaluate the effects of climate change induced salinity intrusion on freshwater aquaculture in Bangladesh. Thus, the present study was conducted to find out the maximum salinity that pangas can tolerate without affecting survival and proximate composition.

\section{MATERIAL AND METHODS}

Experimental fish: Pangas, Pangasius hypophthalmus $(4.68 \pm 0.15 \mathrm{~g}$ and $3.79 \pm 0.25 \mathrm{~cm}$ ) was used as experimental fish which was obtained from the Nirob Fish Hatchery at Mymensingh and transported to Aquatic Laboratory of the Department of Fisheries, University of Dhaka, Bangladesh. Fingerlings were acclimatized in rectangular tanks at freshwater (salinity; 0\%o, temperature; $27.17 \pm 1.97{ }^{\circ} \mathrm{C}, \mathrm{pH} ; 8.14 \pm 0.24$ and $\mathrm{DO} ; 8.33 \pm 0.33 \mathrm{mg} / \mathrm{L}$ ) for two weeks prior to conduct the experiment. All the fish fingerlings showed a normal behavioral pattern during this period.

Experimental system: The experiment was conducted in 40L aquaria, each was stocked with 10 fish fingerlings and the initial weight of fingerlings showed no significant difference among treatments. Pond water was used in the present study. The experiment was conducted during the year 2011-2012.

Experimental Design: Nine treatments were conducted with triplicate groups. The range of salinities selected in this experiment was based on the environmental salinities, as Bangladesh has the huge resource of both freshwater and saline water and has a good connected area between freshwater and saline water. The river flow system is very much helpful to regulate the salinity level. The aquaria were covered with wooden shade to prevent fish from jumping out, and continuous aeration was provided to maintain dissolved oxygen near saturation levels. In each aquarium, $50 \%$ of water volume was renewed every alternative day with water of the salinity selected for the treatment. For the purpose of conditioning 300L static rectangular plastic tank was used. At first, the fish fingerlings were released into the plastic tank at $0 \%$ o 
saline water. After 48 hours of acclimatization 10 fish fingerlings were released in the $0 \%$ o saline water and the rest of the fingerlings were kept inside the plastic tank at $2 \%$ o saline water for the next 48 hours. After another 48 hours of acclimatization 10 fish fingerlings were released in the $2 \%$ o saline water and the rest of the fingerlings were again kept inside the plastic tank at 4\%o saline water for the next 48 hours. Accordingly, the salinity was raised up to $14 \%$ o. Finally uprising of salinity from 14 to $20 \%$ was made which was referred as mega dose. During the acclimatization period, salinity was raised up to $2 \%$ o per 48 hours for all treatments by adding required amount of salt (from Coxes Bazar) for each of the following salinity groups: $0,2,4,6,8,10,12,14$ and $20 \%$. Pangas fingerlings were exposed to these salinities for 60 days. Salinity in each tank was measured once daily.

Maintenance of aquaria and sampling: At 20-day interval length and weight of each fish of each treatment were taken and fish were fed with commercially available pangas feed @ 5\% of their total weight twice a day. Uneaten feed was removed from the aquarium by siphon from the floor. Fifty percent water was exchanged every alternative day and continuous aeration was provided throughout the experimental period. Fish weight and length were recorded to determine the feed efficiency, feed conversion ratio, condition factor, average daily gain and protein efficiency ratio. Sampling was done at $20^{\text {th }}, 40^{\text {th }}$ and $60^{\text {th }}$ day of the experiment.

Growth study: Condition factor $(\mathrm{K})$ was calculated by the following formula as suggested by Hile $(1936) ; \mathrm{K}=\left(\mathrm{w} / \mathrm{L}^{3}\right) \times 100$; Where, $\mathrm{K}$ - condition factor; W- body weight in grams and L- body length in centimeters. Average daily gain was determined by the following formula: $A D G=\left(\mathrm{W}_{2}-\mathrm{W}_{1}\right) / \mathrm{t}_{2}-\mathrm{t}_{1}$ where, $\mathrm{W}_{2}$, final weight, $\mathrm{W}_{1}$, initial weight, $\mathrm{t}_{2}-\mathrm{t}_{1}$ duration of experiment. Specific growth rate (SGR \%) was calculated as the percentage increase in weight per animal per day as suggested by Hopkins (1992), i.e. SGR $(\%)=\mathrm{LnW}_{\mathrm{t}}-\mathrm{LnW}_{1} /(\mathrm{T}-\mathrm{t}) \times 100$. Where, $\mathrm{LnW}_{\mathrm{t}}=$ Natural log of weight at time T; $\mathrm{LnW}_{1}$ Natural $\log$ of initial weight; $\mathrm{T}$ : Time t; Initial time. Food conversion ratio (FCR) was calculated from the weight $(\mathrm{Kg})$ of feed that are used to produce one $\mathrm{Kg}$ of whole fish. Food conversion ratio $(\mathrm{FCR})$ was determined by the following formula: $\mathrm{FCR}=\mathrm{Feed}$ consumed by the fish $(\mathrm{Kg})$ (dry weight basis)/ Live weight of the fish (Kg). Survival rate of fish fingerlings was also determined.

Water quality monitoring: Salinity levels were monitored by using the salinometer (YSI, Japan), pH and DO with pH and DO meter (ITOSENCE, Japan) twice a week.

Proximate analysis: Proximate composition was analyzed according to AOAC (1990) with some modifications as described below. Briefly, for the determination of moisture content $5 \mathrm{~g}$ of sample was dried in an oven at $105{ }^{\circ} \mathrm{C}$ for complete evaporation of moisture. After complete dryness of the sample the loss of moisture was calculated as percent moisture content. For the determination of lipid content, the dried sample left after moisture determination was finely ground and about $0.5 \mathrm{~g}$ were taken in a mortar and macerated with fine sand. Lipid content was then determined using chloroform-methanol method. Ash content was determined from $2 \mathrm{~g}$ of sample which burnt over a flame until it charred and then placed in a muffle furnace at $550{ }^{\circ} \mathrm{C}$ temperature 
for complete combustion. White residue was weighed, and ash content was determined. Crude protein content was determined using the standard microKjeldahl method.

Statistical analysis: Data were analysed by using SPSS (version 11) with a level of significance at $\mathrm{p}<0.05$. One-way ANOVA was done, and significant results were further analyzed using Tukey Test in order to determine ranking and significant differences between treatment means.

\section{RESULTS AND DISCUSSION}

Salinity induced survival and growth of pangas: During the experimental period the survival rate of pangas fingerling was determined from the starting time of the experiment to at the end of 60 days. In case of $0,2,4,6,8,10$ and $12 \%$ o salinity, no mortality was found during the cultural period while Kumar et al. (2017) recorded $86-97 \%$ mortality at the salinity range between 15 and 5\%o. All fish died within 6 hours of stocking at $20 \%$ o salinity while about $50 \%$ died at $14 \%$ o salinity in the same duration (Table 1). Thus, findings of the present study suggest that pangas can be cultured at a salinity of $12 \%$ without any effect on survival.

Table 1. Survival rate (\%) (Mean \pm SEM) of pangas fingerlings in different salinity (\%o) at 60 day rearing period. Means in the same column with different superscripts are significantly different at $\mathbf{P}<0.05$

\begin{tabular}{lllll}
\hline \multirow{2}{*}{ Salinity (\%) } & \multicolumn{4}{c}{ Survival rate (\%) in different duration } \\
\cline { 2 - 5 } & 0 day & 20 day & 40 day & 60 day \\
\hline 0 & $100 \pm 0.0$ & $100 \pm 0.0^{\mathrm{a}}$ & $100 \pm 0.0^{\mathrm{a}}$ & $100 \pm 0.0^{\mathrm{a}}$ \\
2 & $100 \pm 0.0$ & $100 \pm 0.0^{\mathrm{a}}$ & $100 \pm 0.0^{\mathrm{a}}$ & $100 \pm 0.0^{\mathrm{a}}$ \\
4 & $100 \pm 0.0$ & $100 \pm 0.0^{\mathrm{a}}$ & $100 \pm 0.0^{\mathrm{a}}$ & $100 \pm 0.0^{\mathrm{a}}$ \\
6 & $100 \pm 0.0$ & $100 \pm 0.0^{\mathrm{a}}$ & $100 \pm 0.0^{\mathrm{a}}$ & $100 \pm 0.0^{\mathrm{a}}$ \\
8 & $100 \pm 0.0$ & $100 \pm 0.0^{\mathrm{a}}$ & $100 \pm 0.0^{\mathrm{a}}$ & $100 \pm 0.0^{\mathrm{a}}$ \\
10 & $100 \pm 0.0$ & $100 \pm 0.0^{\mathrm{a}}$ & $100 \pm 0.0^{\mathrm{a}}$ & $100 \pm 0.0^{\mathrm{a}}$ \\
12 & $100 \pm 0.0$ & $100 \pm 0.0^{\mathrm{a}}$ & $100 \pm 0.0^{\mathrm{a}}$ & $100 \pm 0.0^{\mathrm{a}}$ \\
14 & $100 \pm 0.0$ & $43.75 \pm 6.25^{\mathrm{b}}$ & $43.75 \pm 6.25^{\mathrm{b}}$ & $43.75 \pm 6.25^{\mathrm{b}}$ \\
20 & $100 \pm 0.0$ & $0.0 \pm 0.0^{\mathrm{c}}$ & $0.0 \pm 0.0^{\mathrm{c}}$ & $0.0 \pm 0.0^{\mathrm{c}}$ \\
\hline
\end{tabular}

Specific growth rate (SGR), is one of the indicators to investigate the growth of fishes. The SGR rate was found at 0 and $2 \%$ o salinity at 20,40 and 60 day. Moreover, at $8 \%$ o salinity maximum SGR was also found at day 60 . On the other hand, lowest SGR was observed at $14 \%$ on 20 day. Salinity of 6, 8, 10 and $12 \%$ o showed moderate SGR (Table 2). Medawars (1945) has demonstrated that "the specific growth rate declines more and more slowly as the organism increases in age" which has been observed in the present study. 
Table 2. Specific growth rate $(\%)$ (Mean \pm SEM) of pangas fingerlings in different salinity $(\% \circ)$ at 60 day rearing period. Means in the same column with different superscripts are significantly different at $\mathbf{P}<0.05$

\begin{tabular}{llll}
\hline \multirow{2}{*}{ Salinity (\%) } & \multicolumn{3}{c}{ SGR \% } \\
\cline { 2 - 4 } & 20 day & 40 day & 60 day \\
\hline 0 & $10.95 \pm 0.25^{\mathrm{a}}$ & $7.10 \pm 0.16^{\mathrm{a}}$ & $5.64 \pm 0.06^{\mathrm{a}}$ \\
2 & $10.30 \pm 0.41^{\mathrm{a}}$ & $6.88 \pm 0.18^{\mathrm{a}}$ & $5.65 \pm 0.06^{\mathrm{a}}$ \\
4 & $10.25 \pm 0.27^{\mathrm{ab}}$ & $6.73 \pm 0.17^{\mathrm{ab}}$ & $5.39 \pm 0.07^{\mathrm{ab}}$ \\
6 & $8.72 \pm 0.27^{\mathrm{bc}}$ & $6.16 \pm 0.13^{\mathrm{bc}}$ & $5.28 \pm 0.07^{\mathrm{bc}}$ \\
8 & $8.55 \pm 0.29^{\mathrm{cd}}$ & $6.13 \pm 0.11^{\mathrm{bc}}$ & $5.35 \pm 0.07^{\mathrm{abc}}$ \\
10 & $7.70 \pm 0.41^{\mathrm{cde}}$ & $5.78 \pm 0.21^{\mathrm{cd}}$ & $5.24 \pm 0.08^{\mathrm{bc}}$ \\
12 & $7.27 \pm 0.27^{\mathrm{de}}$ & $5.57 \pm 0.09^{\mathrm{cd}}$ & $5.03 \pm 0.05^{\mathrm{cd}}$ \\
14 & $6.58 \pm 0.22^{\mathrm{e}}$ & $5.20 \pm 0.07^{\mathrm{d}}$ & $4.94 \pm 0.05^{\mathrm{d}}$ \\
\hline
\end{tabular}

More than a century ago, Minot (1908) has postulated that most animals have the specific growth rate at pick at early stage of their life cycle which typically decreases with increasing age, even becomes zero in some animals. For optimum growth and survival each fish has a specific range of temperature, DO or salinity which are also important for a successful spawn, where a change in one variable can negatively impact on successful reproduction (Barnard and McBain 1994). Findings of the current study demonstrate that pangasgrowth and survival is not affected by salinities up to $4 \%$, while growth was significantly decreased at $8 \%$ salinity and above. This is in agreement with the findings of other study where blacknose silverside and pike silverside fishes have been shown to tolerate salinity up to $5 \%$ and reduced growth and survival at salinities of $10 \%$ and above (Martinez-Palacios et al. 2004).

In the current study, similar FCR was observed in all the treatments during 60-day rearing period (Table 3). Altinok and Grizzle (2001) showed better SGR, and FCR in three freshwater euryhaline species at 3 or $9 \%$ o salinity compared to 0 or $1 \%$ o salinity, which are opposite to the findings of the present study. No significant effect of salinity was found on the FCR in pangas of the present study. However, FCR in pangas in this study was similar to other findings in different fishes (Doolgindachabaporn 1994).

Table 3. Feed conversion ratio FCR (mean \pm SEM) of pangas fingerlings in different salinity $(\%)$ at 60 day rearing period

\begin{tabular}{llll}
\hline \multirow{2}{*}{ Salinity (\%) $)$} & \multicolumn{3}{c}{ FCR } \\
\cline { 2 - 4 } & $20^{\text {th }}$ day & $40^{\text {th }}$ day & $60^{\text {th }}$ day \\
\hline 0 & $2.75 \pm 0.10$ & $2.82 \pm 0.04$ & $2.54 \pm 0.01$ \\
2 & $2.67 \pm 0.20$ & $2.75 \pm 0.05$ & $2.50 \pm 0.11$ \\
4 & $2.43 \pm 0.17$ & $2.70 \pm 0.03$ & $2.49 \pm 0.01$ \\
6 & $2.89 \pm 0.10$ & $2.61 \pm 0.02$ & $2.47 \pm 0.01$ \\
8 & $2.69 \pm 0.08$ & $2.59 \pm 0.03$ & $2.48 \pm 0.01$ \\
10 & $2.48 \pm 0.12$ & $2.57 \pm 0.03$ & $2.48 \pm 0.13$ \\
12 & $2.33 \pm 0.09$ & $2.54 \pm 0.19$ & $2.44 \pm 0.01$ \\
14 & $2.36 \pm 0.05$ & $2.45 \pm 0.01$ & $2.41 \pm 0.01$ \\
\hline
\end{tabular}


The significant difference of average daily gain was observed at the end of 60 days rearing period. The maximum average daily gain was found at 0 and $2 \%$ o salinity and the lowest average daily gain was observed at $14 \%$ o salinity (Table 4). Average daily gain (ADG) was found to be affected by salinity, which was negatively related with increasing salinity. Significantly reduced condition factor was observed at salinity of $6 \%$ and onwards at duration of 20 day while at day 40, condition factor significantly reduced at sanity 12 and $14 \%$ o $(p<0.05$; Table 5). However, the fish were found to be able to maintain condition factor at day 60 in all the salinity conditions.

Table 4. Average daily gain (ADG) (mean \pm SEM) of pangas fingerlings in different salinity (\%o) at 60 day rearing period. Means in the same column with different superscripts are significantly different at $\mathbf{P}<0.05$

\begin{tabular}{cc}
\hline \multirow{2}{*}{ Salinity $(\%)$} & ADG \\
\cline { 2 - 2 } & 60 day \\
\hline 0 & $1.73 \pm 0.04^{\mathrm{a}}$ \\
2 & $1.73 \pm 0.04^{\mathrm{a}}$ \\
4 & $1.56 \pm 0.04^{\mathrm{b}}$ \\
6 & $1.47 \pm 0.03^{\mathrm{b}}$ \\
8 & $1.45 \pm 0.04^{\mathrm{b}}$ \\
10 & $1.43 \pm 0.04^{\mathrm{bc}}$ \\
12 & $1.29 \pm 0.02^{\mathrm{cd}}$ \\
14 & $1.20 \pm 0.02^{\mathrm{d}}$ \\
\hline
\end{tabular}

Condition factor $(\mathrm{K})$ is one of the important growth parameters in fish (Ighwelaet al. 2011). In the current study, salinity was found to decrease the value of condition factor at early stage of culture until day 40 while no effect of salinity was found at late stage of culture (day 60) which might be because of less feeding at higher salinity (Ighwelaet al. 2011). Similar finding has been reported by Sahaet al. (1998)in Clariasbatrachus (Linn.) fed on formulated diets. Rahman et al. (1997) foundthe values of condition factor between 0.81 and 0.87 on the survival and growth of catfish after giving selected supplemental feeds.

Table 5. Condition factor (Mean \pm SEM) of pangas fingerlings in different salinity (\%o) at 60 day rearing period. Means in the same column with different superscripts are significantly different at $\mathbf{P}<0.05$

\begin{tabular}{llll}
\hline \multirow{2}{*}{ Salinity (\%) } & \multicolumn{3}{c}{ Condition factor (K) } \\
\cline { 2 - 4 } & 20 day & 40 day & 60 day \\
\hline 0 & $1.44 \pm 0.08^{\mathrm{a}}$ & $1.04 \pm 0.07^{\mathrm{a}}$ & $1.23 \pm 0.06$ \\
2 & $1.32 \pm 0.07^{\mathrm{a}}$ & $1.30 \pm 0.05^{\mathrm{a}}$ & $1.30 \pm 0.08$ \\
4 & $1.30 \pm 0.05^{\mathrm{a}}$ & $1.29 \pm 0.04^{\mathrm{a}}$ & $1.22 \pm 0.07$ \\
6 & $0.97 \pm 0.03^{\mathrm{b}}$ & $1.27 \pm 0.05^{\mathrm{a}}$ & $1.18 \pm 0.02$ \\
8 & $0.91 \pm 0.03^{\mathrm{b}}$ & $1.15 \pm 0.05^{\mathrm{a}}$ & $1.29 \pm 0.02$ \\
10 & $0.86 \pm 0.03^{\mathrm{bc}}$ & $1.14 \pm 0.04^{\mathrm{a}}$ & $1.30 \pm 0.02$ \\
12 & $0.81 \pm 0.02^{\mathrm{bc}}$ & $1.14 \pm 0.04^{\mathrm{b}}$ & $1.31 \pm 0.02$ \\
14 & $0.68 \pm 0.02^{\mathrm{c}}$ & $1.06 \pm 0.04^{\mathrm{b}}$ & $1.27 \pm 0.01$ \\
\hline
\end{tabular}


Proximate composition of fish and fish feed: Proximate composition is one of the factors that determines the flesh quality of fishes which might be changed due to salinity exposure. The proximate composition was thus determined at different salinity and duration of exposure where lipid, protein and ash content did not show significant variation between treatments and duration except moisture which was found to be increased with increasing salinity with a little fluctuation. The initial proximate composition (mean \pm SEM) of pangas fingerling was determined just after released in different salinity (day zero, Table 6). The lowest amount of moisture $(76.27 \pm 0.04) \%$ was found at $4 \%$ o and the height amount $(78.69 \pm 0.54) \%$ was at $14 \%$ o salinity. Maximum crude protein $17.59 \pm$ $0.23 \%$ was found in $0 \%$ o salinity while minimum $15.56 \pm 0.22 \%$ was found in $14 \%$ o salinity. The highest crude lipid $3.56 \pm 0.24 \%$ was detected at $6 \%$ ond lowest $3.21 \pm 0.18 \%$ was at $14 \%$ and maximum ash content $2.79 \pm 0.08 \%$ was observed at $6 \%$ ond minimum $2.45 \pm 0.14 \%$ was at $4 \%$ o salinity. No significant difference was found in proximate composition of pangas fingerlings at the initial time ( 0 day). On the other hand, after 60 days studied period only moisture showed significant differences among the treatments $(\mathrm{p}<0.05$, Table 7$)$.

Table 6. Initial Proximate composition (\%) (Mean \pm SEM)of pangas fingerlings at day zero $(0)$ of rearing

\begin{tabular}{lllll}
\hline Salinity (\%) & Moisture (\%) & Crude protein $(\%)$ & Crude lipid $(\%)$ & Ash $(\%)$ \\
\hline 0 & $77.18 \pm 0.19$ & $17.59 \pm 0.23$ & $3.51 \pm 0.36$ & $2.66 \pm 0.12$ \\
2 & $77.69 \pm 0.04$ & $16.8 \pm 014$. & $3.22 \pm 0.09$ & $2.60 \pm 0.04$ \\
4 & $76.38 \pm 0.07$ & $17.67 \pm 0.57$ & $3.31 \pm 0.03$ & $2.27 \pm 0.04$ \\
6 & $77.02 \pm 0.66$ & $17.02 \pm 0.01$ & $3.56 \pm 0.24$ & $2.79 \pm 0.08$ \\
8 & $76.39 \pm 0.41$ & $16.66 \pm 0.25$ & $3.32 \pm 0.20$ & $2.54 \pm 0.05$ \\
10 & $78.01 \pm 1.32$ & $16.72 \pm 0.54$ & $3.32 \pm 0.32$ & $2.64 \pm 0.14$ \\
12 & $77.11 \pm 1.31$ & $16.04 \pm 0.52$ & $3.27 \pm 0.07$ & $2.61 \pm 0.38$ \\
14 & $77.50 \pm 0.70$ & $15.56 \pm 0.22$ & $3.21 \pm 0.18$ & $2.45 \pm 0.14$ \\
\hline
\end{tabular}

Table 7. Proximate composition (\%) (Mean \pm SEM) of pangas fingerlings at $60^{\text {th }}$ day of rearing. Means in the same column with different superscripts are significantly different at $P<0.05$

\begin{tabular}{lllll}
\hline Salinity (\%) & Moisture (\%) & Crude protein (\%) & Crude lipid (\%) & Ash (\%) \\
\hline 0 & $76.27 \pm 0.04^{\mathrm{c}}$ & $16.24 \pm 0.06$ & $4.01 \pm 0.10$ & $2.54 \pm 0.21$ \\
2 & $77.74 \pm 0.16^{\mathrm{abc}}$ & $16.24 \pm 0.01$ & $3.62 \pm 0.11$ & $2.50 \pm 0.01$ \\
4 & $76.72 \pm 0.21^{\mathrm{bc}}$ & $17.25 \pm 0.09$ & $3.82 \pm 0.14$ & $2.54 \pm 0.11$ \\
6 & $76.67 \pm 0.34^{\mathrm{bc}}$ & $16.64 \pm 0.35$ & $3.84 \pm 0.17$ & $2.50 \pm 0.11$ \\
8 & $77.48 \pm 0.50^{\mathrm{abc}}$ & $17.37 \pm 0.21$ & $3.80 \pm 0.03$ & $2.43 \pm 0.24$ \\
10 & $77.31 \pm 0.08^{\mathrm{abc}}$ & $15.90 \pm 1.17$ & $3.68 \pm 0.24$ & $2.44 \pm 0.10$ \\
12 & $78.06 \pm 0.08^{\mathrm{ab}}$ & $16.94 \pm 0.90$ & $3.59 \pm 0.08$ & $2.34 \pm 0.34$ \\
14 & $78.69 \pm 0.54^{\mathrm{a}}$ & $16.73 \pm 0.42$ & $3.64 \pm 0.15$ & $2.12 \pm 0.13$ \\
\hline
\end{tabular}


The maximum amount of moisture $78.01 \pm 1.32 \%$ was found at $14 \%$ and minimum $76.38 \pm 0.07 \%$ was in $0 \%$ salinity. The proximate composition of pangas did not show any significant different except moisture. The ranges of moisture, crude protein, crude lipid and ash were $(15.90 \pm 1.17) \%$ to $(17.37 \pm 0.21) \%,(3.59 \pm 0.08) \%$ to $(4.01 \pm 0.10) \%$ and $(2.12 \pm 0.13) \%$ to $(2.54 \pm 0.11) \%$, respectively (Table 7 ). The proximate composition of fish feed was also determined where starter feed contain more crude protein and less moisture than that of grower feed. Both fish feeds were found to contain similar percentage of crude lipid and ash (data not shown).

Water quality parameters: The observed water temperature, $\mathrm{DO}$, and $\mathrm{pH}$ were $27.23 \pm 0.02{ }^{\circ} \mathrm{C}, 8.33 \pm 0.05 \mathrm{mg} / \mathrm{L}$ and $8.05 \pm 0.03$, respectively. No significant variation was found for the observed water quality parameters throughout the experimental period. Water temperature has profound effect on growth, reproduction and other biological activities of fishes. The metabolic rate of fish is closely related to the water temperature. Boyd (1982) reported that the range of water temperature from 26.06 to $31.97{ }^{\circ} \mathrm{C}$ is suitable for warm water fish culture. In the present experiment, the temperature was found $(27.23 \pm$ 0.02) ${ }^{\circ} \mathrm{C}$ which was in suitable range during the entire experiment. Dissolved oxygen (DO) is another important factor that plays a significant role in the productivity of a reservoir. The overall DO was $(8.33 \pm 0.05) \mathrm{mg} / \mathrm{L}$ at present experiment. Oxygen levels of $3 \mathrm{mg} / \mathrm{L}$ and above have been recommended by Ross (2002) for satisfactory level of fish culture. The present result showed appropriate for pangas culture. Hydrogen ion concentration $(\mathrm{pH})$ is very important factor in fish life. Normally $\mathrm{pH}$ ranges from 6.4 to 8.3 is favorable for fish growth (Devi et al. 2017). The optimum range of $\mathrm{pH}$ is 6.5 to 8.5 whereas 7.5 to 8.0 are considered suitable for aquatic organisms. The overall $\mathrm{pH}$ value in the present investigation was $(8.05 \pm 0.03)$ which was suitable for pangas culture.

\section{CONCLUSION}

Pangas is one of the economically important fish species in Bangladesh. The salinity intrusion can result in the reduction of production of this species. However, the results of this study have shown that pangas fingerlings can easily survive at salinity upto $12 \%$. The growth and feed conversion efficiency was found to remain same at salinity of $4 \%$. However, the growth of pangas has been found to be negatively correlated with increasing salinity above 4\%o. The study suggests the necessity of large-scale trial on survival and growth of pangas in saline water.

\section{LITERATURE CITED}

AKTER, R., ASIK, T. Z., SAKIB, M., AKTER, M., SAKIB, M.N., AZAD, A.S.M.A.A., MARUF, M., HAQUE, A. and RAHMAN, M.M. 2019. The Dominant Climate Change Event for Salinity Intrusion in the GBM Delta. Climate, 69: 1-23.

ALTINOK, I., and GRIZZLE. J.M. 2001. Effects of low salinities on Flavobacterium columnare infection of euryhaline and freshwater stenohaline fish. J. Fish Dis. 24(6): $361-367$.

AOAC, 1990. Official Methods of Analysis. 15th Edition, Association of official Analytical Chemists, Washington DC, 685-1298 pp. 
BARNARD, K. and MCBAIN, S. 1994. Standpipe to determine permeability, dissolved oxygen, and vertical particle size distribution in salmonid spawning gravels. Fish Habitat Relationships Technical Bulletin No. 15. U. S. Forest Service.

BOEUF, G. and PAYAN, P. 2001. How should salinity influence growth? Com. Biochem. Physiology 130C: 411-423.

BOYD, C.E. 1982. Water quality management for pond fish culture. Elsevier Sci. Publ. Co. Amsterdam-Oxford-New York-Tokyo, $318 \mathrm{p}$.

BUREL, C., PERSON-LE RUYET, J., GAUMET, F., LE ROUX, A., SEVERE, A. and BOEUF, G. 1996. Effects of temperature on growth and metabolism in juvenile turbot. J. Fish Biol.49: 678692.

DEPARTMENT OF FISHERIES (DOF), 2018. Yearbook of Fisheries Statistics of Bangladesh, 2017-18. Fisheries Resources Survey System (FRSS), Department of Fisheries, Bangladesh: Ministry of Fisheries, 35: $118 \mathrm{p}$.

DOOLGINDACHABAPORN, S. 1994. Development of optimal rearing and culturing system for Climbing perch, Anabas testudineus (Bloch). Doctoral Thesis, University of Manitoba, Canada. 189 pp.

HILE, R. 1936. Age and growth of cisco Leucichthys artedi le Suercur in the lake of north-eastern highland. S. Bull. US. Bur. Fish. 48: 211-317.

HOPKINS, K.D. 1992. Reporting Fish Growth: A Review of the Basics. J. World Aquacul. Society, 23 (3): 173-179.

IGHWELA, AHMED, K.A.A.B. and ABOL-MUNAFI, A.B. 2011. Condition Factor as an Indicator of Growth and Feeding Intensity of Nile Tilapia Fingerlings (Oreochromis niloticus) Feed on Different Levels of Maltose. American-Eurasian J. Agricul. Environ. Sci., 11 (4): 559-563.

IMSLAND, A.K., FOSS, A., GUNNARSSON, S., BERNTSSEN, M. H.G., FITZGERALD, R., BONGA, S.W., HAM, E.V., NÆVDAL, G. and STEFANSSON, S.O. 2001. The interaction of temperature and salinity on growth and food conversion in juvenile turbot (Scophthalmus maximus). Aquaculture 198: 353-367.

KUMAR, A., HARIKRISHNA, V., REDDY, A.K., CHADHA N.K., and RANI. A.M.B. 2017. Salinity Tolerance of Pangasianodon hypophthalmus in Inland Saline Water: Effect on Growth, Survival and Haematological Parameters, Eco. Env. \& Cons. 23 (1), 475-482.

LEMARIE, G., BAROILlER, J.F., CLOTA, F., LAZARD, J. and DOSDAT, A. 2004. A simple test to estimate the salinity resistance of fish with specific application to $O$. niloticus and $S$. melanotheron. Aquaculture 240: 575-587.

MARTINEZ-PALACIOS JORDI, C.A, MORTE, J.C., TELLO-BALLINAS, J.A., CUEVAS, M.T. and ROSS L.G. 2004. The effects of saline environments on survival and growth of eggs and larvae of Chirostoma estor estor Jordan 1880 (Pisces: Atherinidae). Aquaculture 238 (1-4): 509-522.

MEDWARS, P. B. 1945. Size, shape and age in Essays on Growth and Form: Presented to D'arcy Wentworth Thompson, eds. Wilfred Le Gros Clark and Peter Medawar, Oxford: Clarendon Press, $157-187 \mathrm{pp}$.

MINOT, C. S. 1908. The problem of Age, Growth and Death. A study of cytomorphosis based on lectures at the Lowell Institute, March 1907. New York and London, The Science Series, pp. xxii, 280.

RAHMAN, M.A., BHADRA, A., BEGUM, N. and HUSSAIN M.G. 1997. Effects of some selective supplemental feeds on the survival and growth of catfish (Clarias batrachus Lin.) fry. Bangladesh J. Fish. Res.1(2): 55-58.

ROSS, L.L. 2002. Environmental physiology and energetic. Fish and Fisheries Series 25: 89-128.

RUBIA, V.C., SANCHEZ-VAZQUEZ, F.J. and MADRID, J.A. 2005. Effects of salinity on food intake and macronutrient selection in European sea bass. Physiolog.Behaviour 85: 333-339.

SAHA, M. R., MULLAH, M.F.A. and ROY, P.K. 1998. Growth and survival of Clarias batrachus(Lin.) larvae fed in formulated duets. Bangladesh J. Fish. Res. 2(2):151-158.

SUN, L., H. CHEN, HUANG, L. WANG, Z. and YAN, Y. 2006. Growth and energy budget of juvenile cobia (Rachycentron canadum) relative to ration. Aquaculture 257: 214-220.

VARSAMOS, S., WENDELAAR BONGA, S.E., CHARMANTIER, G. and FLIK, G. 2004. Drinking and $\mathrm{Na}+/ \mathrm{K}+$ ATPase activity during early development of European sea bass, Dicentrarchus labrax. Ontogeny and short-term regulation following acute salinity changes. J. Exp. Mar. Biol. Eco. 311: 189-200. 